\title{
KERAGAAN PENYULUH PERTANIAN DALAM UPAYA MENDUKUNG PEMBANGUNAN KETAHANAN PANGAN DI KABUPATEN LAMPUNG BARAT
}

\author{
(Performance of Agriculture Extension in Supporting Food Security Development \\ in West Lampung District)
}

Sri Mustika ${ }^{1}$, Budi Setiawan ${ }^{2}$, dan Dodik Briawan ${ }^{2}$

${ }^{1}$ Program Studi Manaj emen Ketahahan Pangan (MKP), Sekolah Pascasarjana, IPB.
2 Departemen Gizi Masyarakat, Fakultas Ekologi Manusia (FEMA), IPB
Tel: 0251-8628304/ 8621258; Fax: 0251-8625846/ 8622276.

ABST RACT

The objectives of this research were to know correlation and influence of agricultural extension characteristic to their comprehension about main duty and function and their knowledge about food security. This research was conducted in West Lampung District, using cross sectional design. The method of analysis was descriptive and inferential. There were $58.9 \%$ respondents who have a good knowledge of their main duties and about $68.5 \%$ respondents who have knowledge about food security. Education and facilities lead to positive correlation with comprehension for knowledge about food security. But in the contrary it was proved that field of expertise and instruction experiences have negative correlation with knowledge for agricultural extension main duties. The other result is that main duties and function of agriculture extension had significant correlation with knowledge of food security, especially for food consumption.

Keywords: agricultural extension, food security, knowledge.

\section{PENDAHULUAN}

Sesuai dengan visi pembangunan pertanian adalah terwujudnya pertanian tangguh untuk pemantapan ketahanan pangan, peningkatan nilai tambah dan daya saing produk pertanian serta peningkatan kesejahteraan petani. Untuk mewujudkan ketahanan pangan suatu wilayah, diperlukan kebijakan pemerintah yang lebih berpihak kepada petani agar seluruh rangkaian proses produksi pertanian dapat berjalan dengan optimal melalui pencapaian produksi dan stabilitas (kepastian) harga yang menempatkan petani pada posisi tawar yang menguntungkan. Pencapaian tersebut dapat terlaksana bila didukung juga oleh kondisi sumber daya manusia petani dan aparatur yang berkualitas, (Departemen Pertanian, 2006).

Agar usaha peningkatan perilaku masyarakat dilaksanakan lebih terarah, maka penyuluh pertanian selaku aparatur pemerintah diharapkan memiliki kemampuan sehingga dalam pelaksanaan tugasnya, tidak hanya berorientasi pada peningkatan produksi pertanian saja, akan tetapi sampai pada tingkat konsumsi di masyarakat, sesuai dengan salah satu misi pembangunan pertanian tahun 2005 - 2009, adalah mewujudkan ketahanan pangan melalui peningkatan produksi dan penganekaragaman konsumsi.
Sesuai dengan makna otonomi daerah, dalam upaya mendekatkan pelayanan pemerintah kepada masyarakat, penyelenggaraan penyuluhan pertanian dilimpahkan kepada pemerintah daerah kabupaten/kota sesuai dengan surat keputusan Menteri Dalam Negeri nomor 130 tahun 2002, kemudian ditegaskan dengan peraturan pemerintah nomor 41 tahun 2006 tentang organisasi perangkat daerah. Berdasarkan wewenang yang ada pemerintah daerah Kabupaten Lampung Barat telah mengimplementasikan kedalam peraturan daerah nomor 15 tahun 2008 tentang organisasi dan tata kerja lembaga lain sebagai bagian dari perangkat pemerintah daerah. Dalam peraturan daerah tersebut instansi penanggung jawab kegiatan penyuluhan di tingkat kabupaten disebut dengan Badan Penyelelenggara PenyuIuhan Pertanian Perikanan dan kehutanan (BP4K)

Arah revitalisasi pertanian, perikanan, dan kehutanan adalah mewujudkan pertanian tangguh untuk pemantapan ketahanan pangan, maka penyuluh pertanian dituntut memiliki pengetahuan yang memadai di bidang teknis dan non-teknis pertanian untuk mendukung pemantapan ketahanan pangan tersebut. Pengetahuan penyuluh dalam hal ketahanan pangan sangat dipengaruhi oleh beberapa karakteristik penyuluh, seperti pendidikan formal, bidang keahlian, pendidikan non-formal, pengalaman 
menyuluh, pemanfaatan media, pelayanan informasi dan fasilitas penyuluhan, serta pemahaman mengenai tugas pokok dan fungsinya.

Penelitian ini secara khusus bertujuan untuk: 1) menganalisis karakteristik penyuluh pertanian di Kabupaten Lampung Barat; 2) menganalisis tingkat pengetahuan penyuluh pertanian terhadap tugas pokok dan fungsinya sebagai penyuluh pertanian; 3) menganalisis tingkat pengetahuan penyuluh pertanian terhadap ketahanan pangan; 4) menganalisis hubungan tingkat pengetahuan penyuluh pertanian tentang pemahaman tugas pokok dan fungsinya dengan karakteristik penyuluh; 5) menganalisis hubungan tingkat pengetahuan penyuluh pertanian tentang ketahanan pangan dengan karakteristik penyuluh; dan 6) merumuskan upaya-upaya untuk peningkatan pengetahuan tenaga penyuluh dalam pembangunan ketahanan pangan.

\section{METODE PENELITIAN}

\section{Desain dan Tempat Penelitian}

Desain penelitian ini adalah cross sectional dengan metode survei dan pengisian kuesioner, penelitian di lakukan di Kabupaten Lampung Barat. Alasan pemilihan lokasi karena peneliti bertugas di Kabupaten Lampung Barat pada badan penyelenggara penyuluhan pertanian perikanan dan kehutanan (BP4K). Subjek penelitian ini adalah seluruh penyuluh pertanian yang terdapat di Kabupaten Lampung Barat sejumlah 124 orang. Penelitian ini menggunakan seluruh populasi agar hasil penelitian lebih akurat. Wawancara terhadap kepala dinas terkait di Lampung Barat dilakukan untuk mengetahui arah kebijakan pembangunan ketahanan pangan.

\section{Jenis dan Cara Pengumpulan Data}

Data yang digunakan dalam penelitian ini meliputi: data primer yang diperoleh dari penyuluh pertanian yang telah mengisi kuesioner yang telah disiapkan. Data primer meliputi karakteristik penyuluh pertanian yang terdiri atas: pendidikan formal, bidang keahlian, pendidikan non-formal, pengalaman menyuluh, pemanfaatan media, pelayanan informasi dan fasilitas penyuluh, serta pemahaman tentang tugas pokok dan fungsi penyuluh pertanian dan pengetahuan penyuluh tentang ketahanan pangan. Data sekunder diperoleh dari Badan Penyelenggara Penyuluhan Pertanian, Perikanan dan Kehutanan (BP4K) dan instansi terkait lainnya, berupa data potensi Kabupaten Lampung
Barat, data penyuluh dan program dinas instansi terkait tentang ketahanan pangan yang melibatkan penyuluh pertanian dalam pelaksanaan program tersebut.

\section{Pengolahan dan Analisis Data}

Pengolahan dan analisis data menggunakan metode deskriptif dan inferensial pada karateristik penyuluh. Uji korelasi Pearson, dan Spearman digunakan untuk menganalisis hubungan antar karateristik penyuluh dengan pemahaman tupoksi dan pengetahuan ketahanan pangan, sedangkan uj i regresi berganda untuk menganalisis pengaruh pemahaman tupoksi dan pengetahuan ketahanan pangan terhadap karateristik penyuluh

\section{HASIL DAN PEMBAHASAN}

\section{Kondisi Umum Kabupaten Lampung Barat}

Lampung Barat memiliki luas wilayah $4950.40 \mathrm{Km}^{2}$, dengan jumlah penduduk sebanyak 410723 jiwa dan jumlah kepala keluarga 109529 kepala keluarga. Pemanfaatan Iahan untuk bidang pertanian: Iahan sawah 20541.5 $\mathrm{Ha}$, lahan pekarangan $13784 \mathrm{Ha}$, kebun atau ladang $33600 \mathrm{Ha}$, pengembalaan $695 \mathrm{Ha}$, hutan rakyat $24211 \mathrm{Ha}$, perkebunan $79216 \mathrm{Ha}$, dan kolam $1126 \mathrm{Ha}$. Produksi padi tahun 2007 sebesar 149409 ton/tahun atau setara dengan 97115.85 ton beras. Untuk saat ini konsumsi aktual beras penduduk Kabupaten Lampung Barat sebesar $137 \mathrm{~kg}$, bila dikalikan dengan jumlah penduduk Lampung Barat tahun 2007 sebesar 410723 jiwa maka jumlah beras yang dibutuhkan adalah 56269 ton/tahun. Berdasarkan hasil survey pola konsumsi pangan di Kabupaten Lampung Barat tahun 2007 tingkat konsumsi energi 1947 kkal/kapita/hari, sedangkan konsumsi protein 58 gr/kapita/hari, dan pola pangan harapan 78.8.

\section{Pendidikan Formal}

Pendidikan formal adalah tingkat pendidikan formal terakhir yang dicapai penyuluh pada saat penelitian dilaksanakan. Pengkategorian pendidikan formal pada penelitian ini ialah 1) SLTA , 2) Diploma I (D I), 3) Diploma II (D II), 4) Diploma IV (D IV) dan 5) sarjana (S1). Dari hasil penilitaian tentang karakteristik penyuluh berdasarkan pendidikan formal dapat dilihat pada Tabel 1

\section{Bidang Keahlian}

Bidang keahlian adalah keahlian yang dimiliki penyuluh pertanian secara luas yang di- 
kategorikan: 1) keahlian bidang pertanian, 2) bidang perkebunan, 3) bidang peternakan, 4) bidang perikanan, dan 5) bidang kehutanan. Hasil penelitian tentang karaktersistik penyuluh berdasarkan bidang keahlian dapat dilihat pada Tabel 2

Tabel 1. Karakteristik Penyuluh berdasarkan Pendidikan Formal

\begin{tabular}{lrr}
\hline \multicolumn{1}{c}{ Pendidikan } & Jumlah & Persentase \\
\hline SLTA & 68 & 54.8 \\
D1 & 1 & 0.8 \\
D III & 12 & 9.7 \\
D IV & 3 & 2.4 \\
S1 & 40 & 32.3 \\
\hline \multicolumn{1}{r}{ Total } & 124 & 100.0 \\
\hline
\end{tabular}

Tabel 2. Karakteristik Penyuluh berdasarkan Bidang Keahlian

\begin{tabular}{lrr}
\hline \multicolumn{1}{c}{ Bidang Keahlian } & Jumlah & Persentase \\
\hline Pertanian & 67 & 54.0 \\
Perkebunan & 20 & 16.1 \\
Peternakan & 11 & 8.9 \\
Perikanan & 2 & 1.6 \\
Kehutanan & 24 & 19.4 \\
\hline \multicolumn{1}{c}{ Total } & 124 & 100.0 \\
\hline
\end{tabular}

\section{Pendidikan Non Formal}

Pendidikan non formal penyuluh adalah lamanya penyuluh mengikuti berbagai pelatihan teknis atau kursus dalam kurun waktu 3 tahun terakhir yang dihitung dalam satuan jam. Berdasarkan hasil penelitian jumlah jam pelatihan terendah 0 jam (tidak pernah mengikuti pelatihan teknis) dan terbanyak 608 jam. Untuk menentukan kategori pelatihan di tetapkan berdasarkan jumlah jam pelatihan yang mendapatkan kredit poin. Hasil penelitian tentang karakteristik penyuluh berdasarkan pendidikan non formal yang dilihat dari lamanya mengikuti pelatihan teknis dalam satuan jumlah jam, dapat dilihat pada Tabel 3

Tabel 3. Karakteristik Penyuluh berdasarkan Pendidikan Non Formal

\begin{tabular}{lrr}
\hline $\begin{array}{c}\text { Tingkat Pendidikan } \\
\text { Non Formal }\end{array}$ & J umlah & Persentase \\
\hline Sangat rendah $\leq 80$ & 98 & 79.0 \\
Rendah (81-160) & 10 & 8.1 \\
Sedang (161-400) & 15 & 12.1 \\
Tinggi (401-608) & 1 & 0.8 \\
\hline Total & 124 & 100.0 \\
\hline
\end{tabular}

\section{Pengalaman Penyuluh}

Pengalaman menyuluh adalah lamanya petugas menjadi penyuluh dihitung sejak ditugaskan sebagai penyuluh sampai pada saat penelitian dilakukan, pengalaman menyuluh dinyatakan dalam tahun. Berdasarkan hal tersebut pengalaman menyuluh terdiri atas tiga kategori yaitu: 1). sedikit, 2) sedang, dan 3 banyak. Hasil penelitian tentang karaktersistik penyuluh berdasarkan pengalaman menyuluh dapat dilihat pada Tabel 4.

Tabel 4. Karakteristik Penyuluh berdasarkan Pengalaman Menyuluh

\begin{tabular}{crr}
\hline $\begin{array}{c}\text { Pengalaman } \\
\text { Menyuluh }\end{array}$ & J umlah & Persentase \\
\hline Sedikit (0 - 12 tahun) & 52 & 41.9 \\
Sedang (13-24 tahun) & 56 & 45.2 \\
Banyak ( $>25$ tahun) & 16 & 12.9 \\
\hline Total & 124 & 100.0 \\
\hline
\end{tabular}

\section{Pemanfaatan Media}

Pemanfaatan media adalah frekuensi penyuluh dalam mencari dan mendapatkan informasi dari berbagai media komunikasi baik media elektronik maupun media cetak. Pengkategorian untuk pemanfaatan media terdiri atas: 1) tidak pernah, 2) kadang-kadang, 3) sering, dan 4) sering sekali. Hasil penelitian tentang karaktersistik penyuluh berdasarkan pemanfaatan media dapat dilihat pada Tabel 5

Tabel 5. Karakteristik Penyuluh berdasarkan Pemanfaatan Media Cetak

\begin{tabular}{lrc}
\hline $\begin{array}{c}\text { Tingkat Keseringan } \\
\text { Memanfaatkan Media Cetak }\end{array}$ & J umlah & Persentase \\
\hline Tidak pernah & 1 & 0.8 \\
Kadang-kadang & 52 & 41.9 \\
Sering & 56 & 45.2 \\
Sering sekali & 15 & 12.1 \\
\hline \multicolumn{1}{c}{ Total } & 124 & 100.0 \\
\hline
\end{tabular}

\section{Pelayanan Informasi dan fasilitas penyuluhan}

Penggunaan media penyuluhan sebagai salah satu alat untuk menyampaikan informasi oleh penyuluh kepada petani agar materi penyuluhannya lebih mudah diterima dan dimengerti oleh petani, dalam penelitian ini kategori media penyuluhan yang digunakan adalah banyaknya macam media penyuluhan yang digunakan yang dikategorikan 1) sedikit (0-2 macam) 2) Sedang (3-4 macam) 3) banyak (>4 macam). Hasil penelitian tentang karakteristik 
penyuluh berdasarkan penggunaan media penyuluhan dapat dilihat pada Tabel 6

Tabel 6. Karakteristik Penyuluh berdasarkan Penggunaan Media Penyuluhan

\begin{tabular}{crc}
\hline $\begin{array}{c}\text { Tingkat Penggunaan } \\
\text { Media Penyuluhan }\end{array}$ & J umlah & Persentase \\
\hline Sedikit ( 0-2 macam) & 107 & 86.0 \\
Sedang (3-4macam) & 16 & 13.0 \\
Banyak (>4 macam) & 1 & 1.0 \\
\hline Total & 124 & 100.0 \\
\hline
\end{tabular}

Fasilitas penyuluhan adalah salah satu bentuk dukungan yang diberikan oleh organisasi dalam hal ini BP4K untuk memperlancar dan mempermudah pelaksanaan tugas penyuluh. Berdasarkan hasil penelitian fasilitas yang diberikan oleh pemerintah kepada penyuluh untuk memperlancar tugasnya berupa kendaraan bermotor, biaya operasional penyuluh dan koran Sinar Tani.

\section{Pemahaman terhadap Tugas Pokok dan Fungsi Penyuluh Pertanian}

Pengetahuan penyuluh terhadap tugas pokok dan fungsinya sebagai petugas penyuluh merupakan salah satu tolak ukur kemampuan penyuluh dalam melaksanakan tugas dan fungsinya, sesuai dengan Peraturan Menteri Negara Pendayagunaan Aparatur Negara Nomor: PER/ 02/ MENPAN/ 2/ 2008 tahun 2008, tentang Jabatan Fungsional Penyuluh Pertanian dan Angka Kreditnya, Bahwa tugas pokok penyuluh pertanian adalah melakukan kegiatan: 1) persiapan dan perencanaan penyuluhan pertanian, 2) pelaksanaan penyuluhan pertanian, 3) evaluasi dan pelaporan penyuluhan, 4) pengem- bangan penyuluhan dan Pengembangan profesi penyuluh, 5) Kegiatan penunjang penyuluhan.

Untuk mengetahui sejauh mana penyuluh memahami tugas pokok dan fungsinya maka pada penelitian ini penyuluh diminta mengisi kuisioner yang telah disediakan dengan pokok bahasan tingkat pemahaman penyuluh terhadap tugas pokok dan fungsinya.

Berdasarkan hasil penelitian tingkat pemahaman penyuluh terhadap tupoksi didapat nilai terendah 60 dan nilai tertinggi 93, lalu dikategorikan jadi rendah, sedang, dan tinggi. Untuk menentukan rentang pada setiap kategori dengan cara jumlah nilai tertinggi dikurangi nilai terendah di- bagi tiga kategor yaitu: 1) rendah (60-71), 2) sedang (73-84) dan tinggi (84-95). Untuk mengetahui tingkat pemahaman penyuluh terhadap tugas pokok dan fungsinya dapat dilihat pada Tabel 7.

Tabel 7. Karakteristik Penyuluh berdasarkan Pemahaman terhadap Tupoksi

\begin{tabular}{lrc}
\hline Nilai Pemahaman Tupoksi & J umlah & Persentase \\
\hline Rendah ( $60-71$ macam) & 4 & 3.2 \\
Sedang (72 - 83) & 73 & 58.9 \\
Tinggi (84 - 95) & 47 & 37.9 \\
\hline Total & 124 & 100.0 \\
\hline
\end{tabular}

\section{Faktor-Faktor yang Berpengaruh terhadap Pemahaman Tupoksi}

Hasil analisis regresi berganda faktor yang berpengaruh antara karakteristik penyuluh dengan pemahaman tupoksi dapat dilihat pada Tabel 8.

Tabel 8. Faktor-faktor yang Berpengaruh terhadap Tingkat Pemahaman Tupoksi

\begin{tabular}{|c|c|c|c|c|}
\hline \multirow{2}{*}{ Peubah Bebas } & \multicolumn{2}{|c|}{ Unstandardized Coefficients } & \multirow{2}{*}{$\begin{array}{c}\begin{array}{c}\text { Standardized } \\
\text { Coefficients }\end{array} \\
\text { Beta }\end{array}$} & \multirow[t]{2}{*}{ Sig. } \\
\hline & B & Std. Error & & \\
\hline (Constant) & 74.469 & 5.055 & & 2.3E-27 \\
\hline Umur $\left(X_{1}\right)$ & 0.023 & 0.094 & 0.033 & 0.803 \\
\hline Pendidikan $\left(X_{2}\right)$ & 0.598 & 0.246 & 0.224 & 0.017 \\
\hline Pelatihan $\left(X_{3}\right)$ & -0.001 & 0.004 & -0.013 & 0.884 \\
\hline Pengalaman menyuluh $\left(\mathrm{X}_{4}\right)$ & -0.152 & 0.072 & -0.300 & 0.037 \\
\hline Pelayanan Informasi $\left(X_{5}\right)$ & 0.573 & 0.364 & 0.137 & 0.118 \\
\hline Pemanfaatan media massa $\left(X_{6}\right)$ & 0.259 & 0.707 & 0.032 & 0.715 \\
\hline Fasilitas yg diperoleh $\left(D_{1}\right)$ & 4.688 & 1.174 & 0.464 & 0.0001 \\
\hline Keahlian $\left(D_{2}\right)$ & -1.745 & 0.873 & -0.172 & 0.048 \\
\hline $\mathrm{R} 2$ & 0.260 & & & \\
\hline
\end{tabular}

Keterangan

$D_{1}=$ Variabel dummy untuk fasilitas yang diperoleh, 1 (kendaraan bermotor), 0 (lainnya).

$\mathrm{D}_{2}=$ Variabel dummy untuk bidang keahlian, 1 (pertanian), 0 (non pertanian). 


\section{Pendidikan Formal Penyuluh Pertanian}

Hasil analisis regresi berganda menunjukkan pendidikan penyuluh mempunyai pengaruh yang signifikan $(p<0.05)$ terhadap pemahaman tugas pokok dan fungsinya. Hubungan yang positif antara pendidikan penyuluh dengan pemahaman tupoksi berarti bahwa semakin tinggi tingkat pendidikan penyuluh maka akan meningkatkan pemahamannya terhadap tupoksi. Hal ini sesuai dengan pendapat Schemerhorn et al. bahwa pendidikan merupakan proses seseorang dalam memperoleh kemampuan dan kepercayaan diri yang tentu akan sangat mempengaruhi perilakunya dalam organisasi.

\section{Pengalaman Menyuluh}

Pengalaman menyuluh mempunyai pengaruh signifikan negatif dengan pemahaman terhadap tupoksi, ini berarti bahwa semakin lama seseorang menjadi penyuluh belum tentu akan membuat seorang penyuluh menjadi lebih paham tehadap tugas pokok dan fungsinya. Hal ini sejalan hasil penelitian Sufiari Suhanda yang menyatakan bahwa masa kerja penyuluh memberikan efek positif bagi penyuluh yang masih baru, sementara kepada penyuluh yang sudah lebih lama bekerja menunjukkan tingkat kepuasan klien yang rendah.

\section{Fasilitas Yang diperoleh Penyuluh Pertanian}

Hasil analisis regresi berganda menunjukkan fasilitas yang diporoleh penyuluh berpengaruh sangat signifikan $(p<0.05)$ terhadap pemahaman tugas pokok dan fungsinya. Hubungan positif antara fasilitas yang diporoleh penyuluh dengan pemahaman tupoksi menunjukkan bahwa semakin banyak fasilitas yang diterima penyuluh maka pemahamannya terhadap tupoksi makin baik. Hal ini mungkin dikarenakan dengan mendapat fasilitas, penyuluh merasa lebih bertanggung jawab terhadap tugas pokok dan fungsinya.

\section{Bidang Keahlian}

Bidang keahlian penyuluh berpengaruh signifikan $(p<0.05)$ terhadap pemahaman tugas pokok dan fungsi penyuluh, tetapi mempunyai hubungan negatif. J umlah penyuluh pertanian yang lebih banyak daripada penyuluh non pertanian menghasilkan hubungan negatif terhadap pemahaman tupoksi. Hal ini diduga karena penyuluh yang bidang keahliannya pertanian mayoritas adalah penyuluh senior sehingga tingkat kepeduliannya terhadap tupoksi berkurang. Pengkatagorian keahlian penyuluh pada pertanian dan non pertanian memberi pengaruh negatif dalam analisis ini.

\section{Pengetahuan Ketahanan Pangan Penyuluh Pertanian}

Sejauh mana tingkat pengetahuan penyuluh terhadap ketahanan pangan secara luas maka penyuluh diminta mengisi kuesioner yang telah terbagi dalam subsistem ketahanan pangan yaitu subsitem ketersediaan, subsistem distribusi, subsistem konsumsi dan keamanan pangan. Data tingkat pengetahuan penyuluh terhadap ketahanan pangan dapat dilihat pada Tabel 9

Tabel 9. Karakteristik Penyuluh berdasarkan Pemahaman pada Ketahanan Pangan

\begin{tabular}{crc}
\hline $\begin{array}{c}\text { Pengetahuan } \\
\text { Ketahanan Pangan }\end{array}$ & J umlah & Persentase \\
\hline Rendah $(60-71)$ & 20 & 16.1 \\
Sedang $(72-83)$ & 85 & 68.5 \\
Tinggi $(84-95)$ & 19 & 15.3 \\
\hline Total & 124 & 100.0 \\
\hline
\end{tabular}

Faktor-Faktor yang Berhubungan dengan Pengetahuan Ketahanan Pangan

Hasil analisis regresi berganda faktor yang berpengaruh antara karakteristik penyuluh dengan pengetahuan ketahanan pangan dapat dilihat pada Tabel 10.

\section{Pendidikan Formal Penyuluh Pertanian}

Hasil analisis regresi berganda menunjukkan pendidikan formal penyuluh berpengaruh signifikan $(p \varangle 0.05)$ terhadap pengetahuan ketahanan pangan. Hubungan positif antara pendidikan dengan pengetahuan ketahanan pangan menunjukkan bahwa makin tinggi tingkat pendidikan penyuluh maka akan meningkatkan pengetahuan ketahanan pangan. Hal ini sesuai dengan pendapat Schemerhorn et al. (1977) bahwa pendidikan merupakan proses seseorang dalam memperoleh kemampuan dan kepercayaan diri yang akan sangat mempengaruhi perilakunya dalam organisasi.

\section{Fasilitas Yang diperoleh Penyuluh Pertanian}

Hasil analisis regresi berganda menunjukkan fasilitas yang diperoleh penyuluh mempunyai pengaruh $(p \varangle 0.05)$ terhadap pengetahuan ketahanan pangan. Hubungan positif antara fasilitas yang diperoleh penyuluh dengan pemahaman tupoksi menunjukkan bahwa dengan fasilitas yang diterima penyuluh memberikan pengaruh yang makin baik. Hal ini mungkin dikarenakan dengan mendapat fasilitas, penyuluh merasa lebih bertanggung jawab terhadap tugasnya. 
Tabel 10. Faktor-faktor yang Berpengaruh terhadap Pengetahuan Ketahanan Pangan

\begin{tabular}{|c|c|c|c|c|}
\hline \multirow{2}{*}{ Peubah Bebas } & \multicolumn{2}{|c|}{ Unstandardized Coefficients } & \multirow{2}{*}{$\begin{array}{c}\begin{array}{c}\text { Standardized } \\
\text { Coefficients }\end{array} \\
\text { Beta } \\
\end{array}$} & \multirow{2}{*}{ Sig. } \\
\hline & B & Std. Error & & \\
\hline (Constant) & 60.459 & 6.788 & & 9.1E-15 \\
\hline $\operatorname{Umur}\left(\mathrm{X}_{1}\right)$ & 0.081 & 0.126 & 0.086 & 0.524 \\
\hline Pendidikan $\left(\mathrm{X}_{2}\right)$ & 0.881 & 0.330 & 0.248 & 0.009 \\
\hline Pelatihan $\left(X_{3}\right)$ & -0.003 & 0.006 & -0.046 & 0.596 \\
\hline Pengalaman menyuluh $\left(\mathrm{X}_{4}\right)$ & -0.154 & 0.096 & -0.229 & 0.112 \\
\hline Pelayanan Informasi $\left(X_{5}\right)$ & 0.706 & 0.488 & 0.127 & 0.151 \\
\hline Pemanfaatan media massa $\left(\mathrm{X}_{6}\right)$ & 1.789 & 0.950 & 0.166 & 0.062 \\
\hline Fasilitas yg diperoleh $\left(D_{1}\right)$ & 3.774 & 1.576 & 0.280 & 0.018 \\
\hline Keahlian $\left(D_{2}\right)$ & 0.881 & 1.172 & -0.060 & 0.490 \\
\hline $\mathrm{R} 2$ & 0.249 & & & \\
\hline
\end{tabular}

\section{Rumusan Upaya Peningkatan Peranan Penyuluh Pertanian dalam Pembangunan Ketahanan Pangan}

Berdasarkan analisis yang telah dilakukan maka rumusan kebijakan yang dapat direkomendasikan adalah untuk mempermudah penyuluh pertanian mengakses informasi tentang ketahanan pangan dan teknologi baru, perlu adanya suatu sarana atau wadah sebagai tempat bagi penyuluh pertanian untuk mendapatkan informasi yang diperlukan. Pemerintah daerah dalam hal ini BP4K perlu menyediakan perpustakaan bagi penyuluh pertanian, yang berisi buku-buku ilmu pengetahuan, kemudahan akses internet dan kaset-kaset atau Compact Disc (CD) yang berisi pengetahuan tentang teknologi pertanian yang memang sangat diperlukan penyuluh pertanian dan petani. Untuk memberikan pelayanan informasi yang lebih baik dalam melaksanakan tugas penyuluhan, pemerintah daerah perlu menyediakan sarana dan fasilitas berupa alat bantu penyampaian informasi penyuluhan dalam bentuk alat peraga dan kaji terap teknologi.

J umlah penyuluh pertanian yang mempunyai kemampuan dan kinerja baik sangat terbatas. Pemerintah daerah diharapkan tidak dengan mudah mengalihkan petugas jabatan fungsional penyuluh pertanian ke jabatan struktural. Hal ini akan sangat berpengaruh terhadap pelaksanaan program penyuluhan dan juga peningkatan pengetahuan, sikap dan keterampilan petani. Pada ahirnya dapat mempengaruhi pelaksanaan pembangunan pertanian yang ada di masyarakat termasuk di dalamnya pembangunan ketahanan pangan.

Penyuluh pertanian yang berprestasi atau bekerja dengan baik agar diberikan penghargaan berupa piagam penghargaan, tabungan pendidikan bagi putera-puterinya atau memberikan kesempatan kepada penyuluh pertanian yang berprestasi untuk melaksanakan ibadah haji. Biasanya seseorang setelah mendapatkan predikat haji akan merasa lebih bertanggungjawab terhadap tugasnya dan masyarakat di sekitarnya akan lebih menghargai dan memerlukannya. Pemberian penghargaan atas kinerja penyuluh pertanian juga dapat dilakukan dalam bentuk tunjangan jabatan penyuluh pertanian yang setara dengan tunjangan jabatan struktural serta memberikan kemudahan dalam proses kenaikan pangkat jabatan fungsional penyuluh pertanian.

Perlu adanya program pelatihan yang berkelanjutan baik yang difasilitasi oleh BP4K dengan melibatkan dinas/ instansi/ kantor yang terkait sebagai narasumber dengan memperbanyak materi pelatihan tentang pengetahuan ketahanan pangan. Penyuluh pertanian diberi kesempatan untuk mengikuti pelatihan teknis yang diselenggarakan oleh penyelenggara pelatihan lainnya. Sedangkan bagi penyuluh pertanian yang tingkat pendidikannya masih SLTA diberi kesempatan untuk melanjutkan jenjang pendidikan yang lebih tinggi, misalnya D III atau Sarjana, terutama pada jurusan program pendidikan ketahanan pangan yang dibiayai pemerintah daerah.

\section{KESIMPULAN}

Karakteristik penyuluh pertanian di kabupaten Lampung Barat sangat beragam, sebagian besar penyuluh pertanian di Lampung Barat mempunyai tingkat pendidikan SLTA dengan bidang keahlian terbanyak pada bidang pertanian dan paling sedikit bidang perikanan. J umlah penyuluh pertanian yang mengikuti pelatihan sangat sedikit. Berdasarkan pengalaman menyuluh terdapat rentang yang jauh an- 
tara penyuluh yang sudah lama dengan penyuluh baru. Mayoritas penyuluh pertanian telah memanfaatkan media cetak maupun media elektronik untuk menambah wawasannya sedangkan fasilitas seluruh penyuluh pertanian mandapatkan dana BOP dan koran Sinar Tani, dan sebahagian penyuluh pertanian telah mendapatkan motor dinas.

Secara umum penyuluh pertanian sudah cukup memahami tugas pokok dan fungsinya. Terdapat (58.9\%) yang tingkat pemahamannya sedang dan $37 \%$ penyuluh pertanian yang tingkat pemahamannya tinggi. Masih terdapat 3.2\% penyuluh pertanian yang tingkat pemahaman terhadap tupoksinya sangat rendah.

Tingkat pengetahuan penyuluh pertanian terhadap ketahanan pangan mayoritas pada kategori sedang (68.5\%), kategori tinggi sebanyak $15.3 \%$ dan kategori rendah sebanyak $16.1 \% \mathrm{Hal}$ ini menunjukkan terdapat penyuluh pertanian pertanian yang tingkat pengetahuan ketahanan pangannya masih rendah, sehingga perlu diberikan pelatihan tentang pengetahuan ketahanan pangan.

Terdapat pengaruh yang positif dan signifikan karakteristik penyuluh pertanian, yaitu pendidikan dan fasilitas yang diperoleh, dengan tingkat pemahaman tugas pokok dan fungsi penyuluh pertanian, akan tetapi terdapat pengaruh signifikan negatif antara karakteristik pengalaman menyuluh dan bidang keahlian terhadap pemahaman tugas pokok dan fungsi penyuluh pertanian.
Terdapat pengaruh yang positif dan signifikan antara karakteristik penyuluh pertanian, yaitu pendidikan dan fasilitas yang diperoleh, dengan tingkat pengetahuan ketahanan pangan. Terdapat hubungan yang signifikan antara pemahaman tupoksi dengan pengetahuan ketahanan pangan terutama pada sub sistem konsumsi pangan.

\section{DAFTAR PUSTAKA}

Badan Pusat statistik Kabupaten Lampung Barat. 2007. Lampung Barat dalam Angka. BPS Lampung Barat, Lampung.

Departemen Pertanian RI. 2005. Rencana Pembangunan Pertanian 2005-2010. Deptan, J akarta.

Departemen Pertanian RI. 2007. Peraturan Menteri Pertanian tentang Pedoman Pembinaan Kelembagaan Petani 2007

Mardikanto T. 1993. Penyuluhan Pembangunan Pertanian. 11 Maret University Press, Surakarta.

Murfiani F. 2006. Kompetensi Penyuluh dalam Pengembangan Modal Usaha kecil di Bidang Pertanian. Tesis Magister, Fakultas Pasca Sarjana IPB, Bogor.

Suhanda NS. 2008. Hubungan Karakteristik dengan Kinerja Penyuluh Pertanian di Propinsi Jawa Barat. Disertasi Doktor, Fakultas Pasca Sarjana IPB, Bogor. 